African Crop Science Journal by African Crop Science Society is licensed under a Creative Commons Attribution 3.0 Uganda License. Based on a work at www.ajol.info/ and www.bioline.org.br/cs DOI: https://dx.doi.org/10.4314/acsj.v29i3.1

\title{
CHANGES IN ENDOGENOUS LEVELS OF IAA AND PAA IN RICE SEED DURING DEVELOPMENT, PREDICTION OF AUXIN SIGNALING PROTEINS AND DOCKING FOR ITS BINDING EFFICIENCY WITH AUXIN MOLECULES
}

\author{
V.M. JHALA, K.S. CHUDASAMA and V.S. THAKER
}

Plant Biotechnology and Molecular Biology Laboratory, Department of Biosciences, Saurashtra University, Rajkot, 360 005, Gujarat, India

Corresponding author: thakervs@gmail.com

(Received 23 September 2020; accepted 17 August 2021)

\begin{abstract}
Indole-3-acetic acid (IAA) and phenyl acetic acid (PAA) are two major physiologically active auxins, found in higher plants. The objective of this study was to evaluate changes in the endogenous levels of IAA and PAA in rice (Oryza sativa) seed and predict probable transporter and efflux (signaling) proteins for docking with auxins from the available rice genome data. IAA and PAA were estimated during rice seed development using sensitive and specific antibodies against each hormone. The levels of IAA and PAA were higher when sink size development was at its peak, suggesting an important role played by the auxin in sink size development of rice seed. Furthermore, auxin binding transporters proteins of rice were confirmed for docking purpose and compared with Arabidopsis and maize proteins. In this context, PAA docked with known IAA proteins; although, docking score of IAA was higher than that of PAA in rice seed. Twelve genes of the auxin efflux carrier (PIN family) of rice were also analysed for phylogeny relatedness with Arabidopsis and maize, to further understanding auxin concentrations and efflux within rice seeds. The predicted PIN proteins for IAA efflux of rice showed docking affinities with PAA, revealed its role in maintaining physiological concentrations of auxins in rice seeds.
\end{abstract}

Key Words: Immunoassay, Indole-3-acetic acid, Oryza sativa, phenyl acetic acid

\section{RÉSUMÉ}

L'acide indole-3-acétique (IAA, Indole-3-acetic acid) et l'acide phénylacétique (PAA, phenyl acetic acid) sont deux auxines physiologiquement actives majeures, trouvées dans les plantes supérieures. L'objectif de cette étude était d'évaluer les changements dans les niveaux endogènes d'IAA et de PAA dans les graines de riz (Oryza sativa) et de prédire les protéines de transport et d'efflux (signalisation) probables pour l' amarrage aux auxines à partir des données disponibles sur le génome du riz. L'IAA et le PAA ont été estimés au cours du développement des semences de riz en utilisant des anticorps sensibles et spécifiques contre chaque hormone. Les niveaux d'IAA et de PAA étaient plus élevés lorsque le développement de la taille du puits était à son maximum, suggérant un rôle important 
joué par l'auxine dans le développement de la taille du puits des graines de riz. De plus, les protéines transporteuses de liaison aux auxines du riz ont été confirmées à des fins d'amarrage et comparées aux protéines d'Arabidopsis et de maïs. Dans ce contexte, le PAA s'est amarré à des protéines IAA connues ; cependant, le but d'amarrage de l'IAA était plus élevé que celui du PAA dans les semences de riz. Douze gènes du transporteur d'efflux d'auxine (famille PIN) du riz ont également été analysés pour la phylogénie avec Arabidopsis et le maïs, afin de mieux comprendre les concentrations d'auxine et l'efflux dans les graines de riz. Les protéines PIN prédites pour l'efflux d'IAA du riz ont montré des affinités d'amarrage avec le PAA, ont révélé son rôle dans le maintien des concentrations physiologiques d'auxines dans les graines de riz.

Mots Clés: Immunoessai, acide indole-3-acétique, Oryza sativa, acide phénylacétique

\section{INTRODUCTION}

Auxins play a decisive role in almost all processes of plant cell growth and development. Auxin molecules are known to regulate cell division (Tank et al., 2014), apical dominance (Reinhardt et al., 2002), lateral root formation (Hidehiro et al., 2007), primordia formation in leaf and flowers (Dubrovsky et al., 2008), cell elongation (Gokani and Thaker, 2002), and sink size development (Chudasama and Thaker, 2007). In all these, the physiological concentration of auxin is the most important element for the effective functions of the cell. Although, IAA is the most studied auxin in plants, other molecules that possess auxin activities are also widely studied; namely PAA (Wightman and Lightly, 1982), Indole-3butyric acid (IBA) (Sauer and Kleine-Vehn 2011) and 4-Chloroindole-3- acetic acid (4cl-IAA) (Reinecke, 1999). In addition, naturally present cumarin acetic acid (CAA) was also demonstrated to possess auxin activities in in vitro grown cotton fiber (Barai et al., 2005).

Auxin status in the cell is reported as (i) free form which is readily available for growth; (ii) conjugated form this released as and when required by the cell for metabolism; otherwise remained stored (Gokani and Thaker, 2002; Chudasama and Thaker, 2006/7); and (iii) the oxidised form as a result of IAA oxidase or peroxidases activities, participate in cessation of growth (Thaker, 1998). The concentration of free forms depends upon the rate of synthesis (Thaker et al., 1986), transport from cell to cell (Nakum et al., 2013) and availability of the receptor molecules (Trevawas, 1982). The concentration of the conjugated forms depends on the availability of conjugating molecules in the cell and oxidised form regulated by the enzyme activities of auxin oxidases (Thaker, 1998).

Physiological functions of the auxins are regulated by a suite of protein molecules that participate in auxin influx at the apex of the cell, to efflux from the base to the next cell of the plant (Trevawas, 1982). Formation of protein-protein complex and its turnover is a key point in auxin signaling. Two major groups of proteins participate in auxin functions; namely (i) auxin binding and transporter proteins; and (ii) efflux transporter proteins. Furthermore, auxins are perceived by two class of receptors, namely the ABP1 extracellular receptor (Xu et al., 2014), and intracellular TIR1/AFB class receptors (Mockaitis and Estelle, 2008).

Four auxin signaling orthologous genes for TIR1 are present in the rice genome (https:// rgp.dna.affrc.go.jp/index.html; https:// www.ncbi.nlm.nih.gov); however, their protein structure is not known. Furthermore, ASK1 and culline1 (Cul1) were reported to form a complex with TIR1, which regulates IAA signaling in Arabidopsis (Dharmasiri et al., 2005a; 2005b). But molecules transporting PAA are missing in the literature for any plant. The proteins of Arabidopsis can be used as 
model to predict proteins structure in rice and to understand its probable function in auxin efflux/influx for IAA and PAA.

Auxin efflux is regulated by the second set of proteins known as the Polarised auxin transport (PIN) family (Køeèeket al., 2009). A total of 12 such PIN proteins identified in the higher plants has a role in auxin efflux in the cells. In A. thaliana, 8 PIN proteins are reported. In maize and rice, 12 PIN proteins are present and from these, PIN9 and PIN 10 are reported only in monocots (Cristian et al., 2012).

Rice (Oriza sativa) is an important cereal crop grown worldwide for human consumption. Development of rice seed on panicle from the day of flowering to maturation passes through the series of metabolic events, which are regulated by the hormones. Auxins present in the developing seed cell participate in cell division and cell elongation, which finally determine seed size (Bhatt and Thaker, 2008, Chudasama and Thaker, 2008). Estimation of endogenous hormones is technically difficult because they are synthesised in minute quantities; as low as $10^{-5} \mathrm{M}$ concentration (Trevawas, 1982). Immunoassays are sensitive and reliable for accurate estimation at low concentrations (Weiler et al., 1981), and therefore, an attempt has been made to evaluate endogenous concentrations using antibodies raised against each, IAA and PAA. It is presumed that changes in IAA and PAA levels will help to understand the role of these molecules in the rice seed development.

To understand the molecular basis of physiological responses of auxin in tissues containing different levels of auxins, it is important to know the auxin sensitivities to TIR1 and ABP1 proteins in rice. The compact nature of the rice genome provides a distinct advantage in gene isolation and genomic sequencing, and thus the rice species has been selected as a target species for genome research by a number of research groups worldwide (Wang et al., 2009; Chen et al., 2014). The objective of this study was to investigate the endogenous IAA and PAA from rice seed and auxin binding capacities with transporter and efflux protein.

\section{MATERIALS AND METHODS}

Plant sampling and hormone assay. Rice (Oryza sativa), varieties GR-11 was grown at the ASPEE research foundation, TANSA Farm, in Mumbai $\left(19^{\circ} 11^{\prime} 299188^{\prime \prime} \mathrm{N}, 72^{\circ}\right.$ 50' 308076' E) in India. The cultural practices including irrigation, application of fertilisers, insecticides and pesticides were conducted as normal field practices. From the day of anthesis, uniformly growing panicles in the field were tagged to minimise variations in sampling (Jhala and Thaker, 2015) and harvested every day from day 1 until maturity for hormone analysis.

Estimation of hormones. Seeds (approx:150$500 \mathrm{mg}$ ) of different ages were crushed with liquid nitrogen and mixed with extraction solution containing $5 \mathrm{ml}$ of $80 \%$ methanol ( $\mathrm{v} /$ v) and $100 \mathrm{mg} \mathrm{L}^{-1}$ ascorbic acid as an antioxidant. The mixture was stirred at 100 rpm using a magnetic stirrer and incubated for $48 \mathrm{hr}$ at $4^{\circ} \mathrm{C}$ in dark. The mixture was centrifuged at $10,000 \mathrm{~g}$ for 10 minutes at $0^{\circ} \mathrm{C}$, to collect supernatant. Its pellets were washed twice in extraction solution and the pooled supernatant was concentrated using lyophiliser. These extracts were used as sample sources of hormones for estimation, after partial purification on PVPP column as described by Gokani and Thaker (2002).

Estimation of IAA and PAA concentrations. Endogenous levels of IAA and PAA were estimated using specific antibodies against each by a comparatively more sensitive and specific technique, i.e. indirect ELISA, standardised using internal standards and second rabbit IgG tagged with peroxides (Gokani and Thaker, 
2002). In a nut shell, PGR-casein conjugate $(300 \mu \mathrm{l})$ was coated on ELISA plate and incubated for overnight at $4{ }^{\circ} \mathrm{C}$. This was followed by washing with PBS-T, and then by blocking of free protein binding sites of well with egg albumin and incubated for $1 \mathrm{hr}$ at $37^{\circ} \mathrm{C}$. Antibodies against PGRs (either IAA or PAA) mixed with samples separately for the each data points and were coated and incubated for $3 \mathrm{hr}$ at $37{ }^{\circ} \mathrm{C}$. Finally, the plate was coated with anti-Rabbit IgG, tagged with peroxidase and the colour was developed using $\mathrm{O}$-phenylenediamine as a substrate. The reaction was terminated by addition of $6 \mathrm{~N}$ sulfuric acid $(50 \mu \mathrm{l})$. After each coating, the ELISA plate was washed thoroughly with PBS containing $005 \%$ Tween-20. The colour developed was measured at $490 \mathrm{~nm}$ by ELISA Reader ( $\mu$ Quant, Biotek, USA). The assay for each hormone was performed thrice and the respective mean values were calculated.

Raising of antibodies. To raise antibodies against IAA and PAA, IAA-BSA (Weiler, 1981) and PAA-BSA (Gokani and Thaker, 2002) conjugates were prepared. Antibodies raised earlier (Patel and Thaker, 2007) were purified for IgG using DEAE cellulose chromatography. The purified antibodies were lyophilised and stored at $-20{ }^{\circ} \mathrm{C}$, until when it was used. For estimation of IAA and PAA, each hormone conjugate was prepared with casein instead BSA to avoid cross reactivity of the conjugated protein (Gokani and Thaker, 2002).

Calibration for IAA and PAA. A calibration curve prepared for IAA and PAA showed a linear relationship with concentration, in the range 50-400 and 25-250 ng per well, for IAA and PAA, respectively. For preparation of the calibration curve, standards of 25-500 ng per well, were mixed with an optimum dilution of antibodies $(1: 10,000)$ instead of samples prior to coating on the plate. Dilution of samples and addition of internal standard to test the sensitivity of the assay was done in this calibration range. With each plate, at least 3-5 known concentrations of either IAA or PAA were measured as standard for calibration for assay validation to avoid experimental errors. Approximately 20 samples in triplicates were assayed per plate; while the remaining wells of the 96 well plate contained positive controls (known concentration of auxin), negative controls (only reaction mixture) and randomly selected samples with internal standard were also included. All estimations were done in triplicates.

Statistical analysis. Data for the hormone concentrations were taken in triplicates and the mean values calculated. The samples with internal standard and calibration were used to validate the assay from each plate. As such, samples with and without internal standards were calculated. By using calibration value, each data point was calculated. A P-value of $1 \%$ or less were considered significant for data interpretation.

In silico analysis of signaling molecules. In silico work were categorised in three parts as below

(i) Auxin receptor proteins prediction form rice sequences:

Known auxin binding and signaling proteins structure were derived from PDB (https://www.rcsb.org/) i.e. from Zea maize and Arabidopsis thaliana respectively. Auxin binding structure and signaling proteins were pBLAST in UNIPROT (https://www.uniprot. org/). UNIPROT ID with maximum BLAST scores in rice used for Rice Protein prediction study. Uniprot databases containing protein sequences of SKP1 (UniProtKB: Q6PL11) and TIR1 (UniProtKB: Q0DKP3), were used for prediction of rice proteins; UniProtKB accession code of the target protein as 
input for modeling. The retrieved sequences of rice were used for protein prediction in SWISS Model (https:// swissmodel.expasy.org/).

(ii) Docking of auxin receptor proteins of Arabidopsis thaliana, maize and rice with auxins(IAA and PAA):

Predicted proteins of rice were confirmed using Protein Structure Comparison Tool V.3.0.8 (jCE V.1.1). Molegro Virtual Docker program has been used for docking of known and predicted proteins with IAA and PAA molecules.

(iii) Multiple sequence alignment and phylogenetic analysis of auxin efflux carriers and membrane prediction:

To perform a phylogenetic analysis of Polarised Auxin Transport (PIN) proteins sequences, we collected sequences form https://www.uniprot.org of rice, Zea maize and Arabidopsis sequences. Uniprot ID of Oryza sativa. UPGMA Phylogenic analysis work had been performed in CLC workbench-5 to know the relationship between $A$. thaliyana (dicot), maize and rice (monocot) PIN family proteins.

The HMMTOP (Hidden Markov Model for Topology Prediction) transmembrane topology prediction server(http://www.enzim.hu/ hmmtop/) was used for rice PIN sequences OsPIN1a, OsPIN1b, OsPIN1c, OsPIN1d, OsPIN2, OsPIN3a, OsPIN3b, OsPIN5a, OsPIN5b, OsPIN5c, OsPIN8 and OsPIN9 membrane prediction.

\section{RESULTS AND DISCUSSION}

To understand the role of auxins in rice seed development, growth phase demarcation of the seed is imperative. Growth phases can be determined with data of DMA and water content. The amount of dry matter represents seed capacity to accumulate photosynthates, and ultimately seed size. Seed enters into maturation phase when water content in the seed decreased. Thus the correlation between these two growth parameters helps in the determination of seed growth phases (Jhala and Thaker, 2015).

IAA and PAA levels in the developing seeds. Figure 1a presents changes in IAA levels from anthesis until maturity. IAA levels were higher during early seed growth than in later stages; and increased during cell division and cell elongation phases (Fig. 1a) and peaked on the $5^{\text {th }}$ day. It then declined and remained very low levels during the latter stages of seed development. Similarly, PAA levels were recorded higher in the early cell division stage, declined gradually in elongation phase and remained at very low levels during latter stages (Fig.1b). When the ratio of PAA to IAA was worked out at given stage of growth and development of the seed, values were higher during early stages (data are not presented) than later growth phases. Overall PAA levels were generally slightly higher than that of IAA initially.

The role of auxins in cell division and elongation is elaborated in many systems (Whightman and Lightly, 1982; Patel and Thaker, 2004; Chudasama and Thaker, 2008). It was demonstrated that longer cotton fibers had more IAA and PAA than their shorter counterparts and addition of IAA or PAA to in vitro grown cotton fibers significantly increased the fiber length (Gokani and Thaker, 2002). Many plant systems were reported with high PAA than IAA at physiological concentrations (Whightman and Lightly, 1982). In our laboratory also in many systems like internodes development (Patel and Thaker, 2004), cotton fiber (Gokani and Thaker, 2002), cotton seed (Bhatt and Thaker, 2008) and seeds of Cajanus cajan (Chudasama and 
(a)

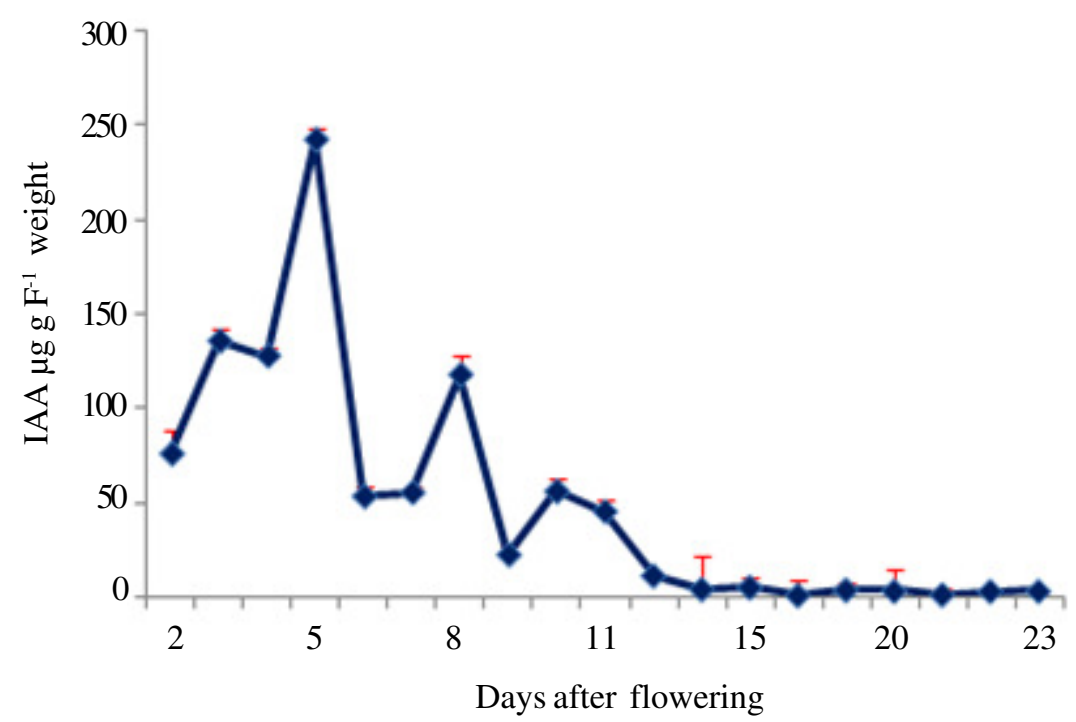

(b)

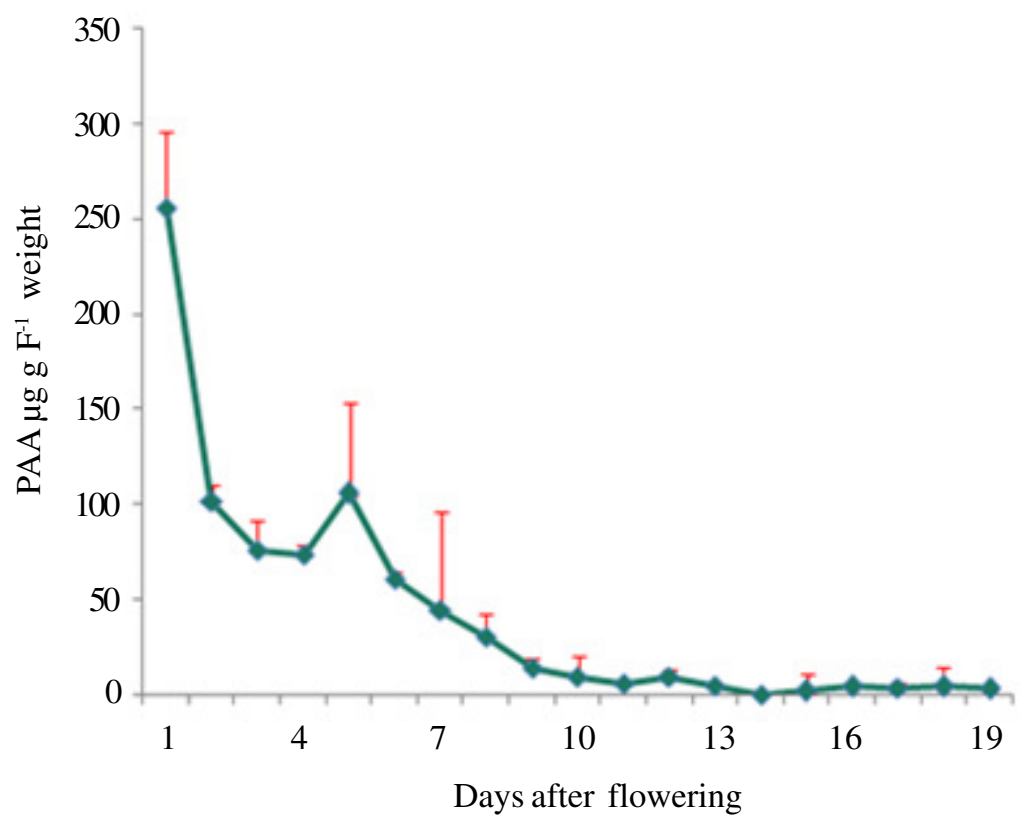

Figure 1. Change in IAA $\mu g \mathrm{FW}^{-1} \mathrm{gm}$ (a) and PAA $\mu \mathrm{g} \mathrm{FW}{ }^{-1} \mathrm{gm}(\mathrm{b})$; in variety GR-11against seed age in days. 
Thaker, 2008) higher PAA than IAA have been reported, suggesting that cells required more PAA than IAA for physiological functions. It is thus likely that IAA and PAA play important roles in cell division and elongation phases in rice seed as well; and hence sink size development.

ABP1 and TIR1 binding with auxins (IAA and PAA). Ligands used for docking are presented in Table 1. SWISS-MODEL (http:/ /swissmodel. expasy.org/) was used for rice protein prediction. Properties of auxin binding protein, transport inhibitor response 1(TIR1) and S-phase kinase-associated protein are presented in Figures 2a, b and c, respectively. Score of Predicted Protein (Table 2), in that Z-score, RMSD, Score, Align-length, Gaps, and Identity given for Predicted Protein of rice using Similarity Protein Structure Comparison Tool V 3.0.8 (jCE V.1.1). Docking results has been obtained for each ligand with the receptors was analysed with docking energy and interaction of each ligand (Table 3); rice ABP showed $90.00 \%$, SKP1 showed $70.30 \%$ and TIR1 showed $76.45 \%$ similarity.

It was observed that PAA and IAA can dock with predicted proteins. IAA binds more efficiently with ABP1 (Table 3). PAA molecules are demonstrated for passive uptake of plant cells (Sibu and Petra, 2011); however, in the present study, PAA binds strongly to ABP1.
Similarly, docking of PAA with ABP1 from maize was also demonstrated (Lobler and Klambt, 1985) and PAA induced some conformation change in structure of ABP1 (Napier and Venis, 1990). This further supports the acclaim that the mechanism of PAA action may include ABP1. Although, the chemical nature of plant hormones does not predict the cellular location of the receptor, the binding of hormone to receptors caused a conformational change to initiate the transduction of the signal; and once activated, receptors could alter gene expression directly by acting as transcriptional factor (Skoog and Miller, 1957). The second class of auxin receptors is believed to be intracellular TIR1/ AFB class receptors, in contrast with ABP1 as extracellular receptor (Xu et al., 2014). Predicted proteins SKP and TIR1 of rice showed IAA binds more efficiently and TIR1 and SKP, together dock with IAA and PAA shows more efficiently with IAA.

Phylogenetic analysis and membrane prediction of OsPINs. PIN proteins act as auxin exporters, in rice OsPIN1a, OsPIN1b, OsPIN1c, OsPIN1d, OsPIN2, OsPIN3a, OsPIN3b, OsPIN5a, OsPIN5b, OsPIN5c, OsPIN8, and OsPIN9 PIN protein sequences download from UniProtKB. Paponov et al. (2005) reported that Phylogenetic analysis using the detected OsPIN proteins and AtPINs

TABLE 1. Selected ligand list detail

\begin{tabular}{lll}
\hline Compound name & IAA & PAA \\
\hline PubChem ID & 802 & 999 \\
Molecular Weight & $175.18396 \mathrm{~g} \mathrm{~mol}^{-1}$ & $136.14792 \mathrm{~g} \mathrm{~mol}^{-1}$ \\
Molecular Formula & $\mathrm{C}_{10} \mathrm{H}_{9} \mathrm{NO}_{2}$ & $\mathrm{C}_{8} \mathrm{H}_{8} \mathrm{O}_{2}$ \\
Canonical SMILES & $\mathrm{C} 1=\mathrm{CC}=\mathrm{C} 2 \mathrm{C}(=\mathrm{C} 1) \mathrm{C}(=\mathrm{CN} 2) \mathrm{CC}(=\mathrm{O}) \mathrm{O}$ & $\mathrm{C} 1=\mathrm{CC}=\mathrm{C}(\mathrm{C}=\mathrm{C} 1) \mathrm{CC}(=\mathrm{O}) \mathrm{O}$ \\
3DConformer & & \\
& & \\
& &
\end{tabular}


(a)

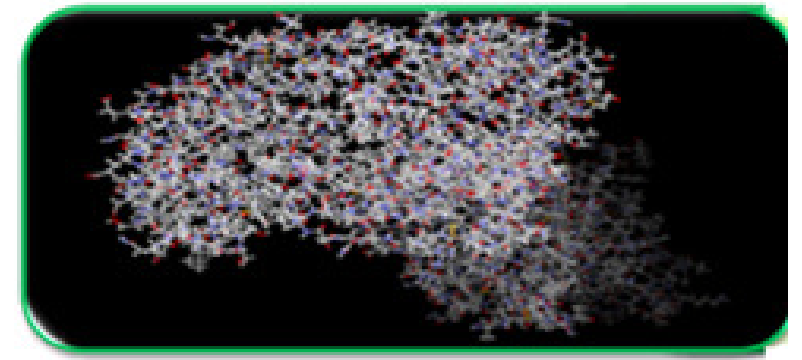

Protein

and ligand

(b)

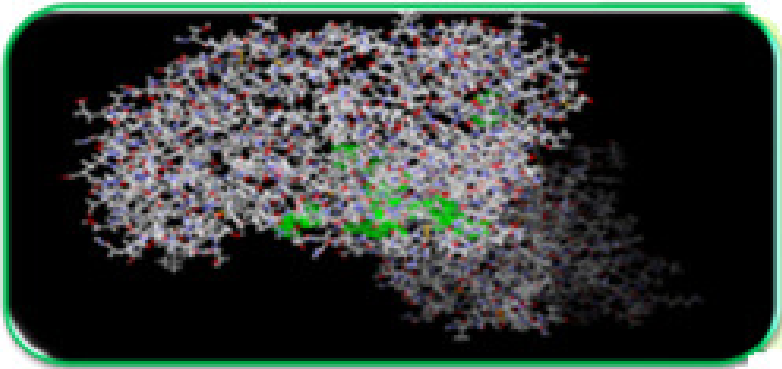

Cavity

detation

(c)

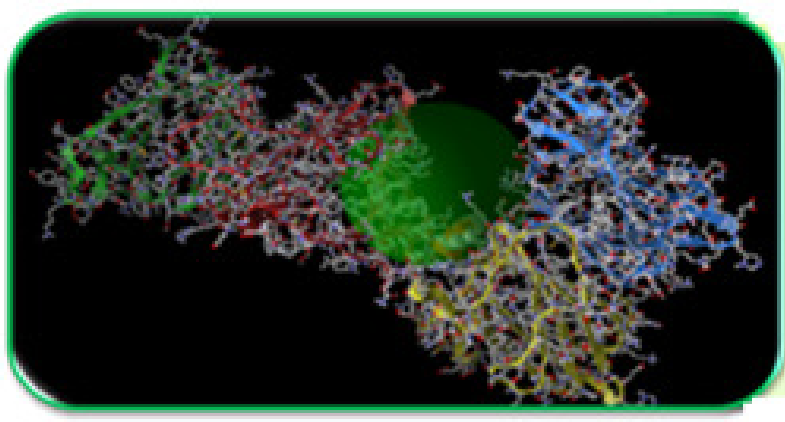

Docking

and pose

view of

ligand

Figure 2 (a). Properties of Rice auxin binding protein (Swiss dock:http://swissmodelexpasyorg/), (b) Properties of Rice transport inhibitor response 1(TIR1) (Swiss dock:http://swissmodelexpasyorg/), and (c) Properties of Rice S-phase kinase-associated protein (Swiss dock:http://swissmodelexpasyorg)

TABLE 2. Score data of predicted protein in Protein Structure Comparison Tool V 3.0.8 (jCE V.1.1)

\begin{tabular}{llcccccc}
\hline Protein name & Z-score & RMSD & Score & Align-length & Gaps & Identity & Similarity \\
\hline RICEABP & 7.93 & 0.43 & 840.48 & 320 & $0 \%$ & $83.13 \%$ & $90.00 \%$ \\
RICESKP1 & 5.33 & 1.06 & 190.76 & 165 & $24.50 \%$ & $64.86 \%$ & $70.30 \%$ \\
RICETIR1 & 8.4 & 0.59 & 1439.84 & 569 & $2.11 \%$ & $60.81 \%$ & $76.45 \%$ \\
\hline
\end{tabular}

showed similar results. The phylogenetic relationships between PINs of dicots and monocots were determined through a UPGAM phylogenetic analysis, which also allowed determination of the relationship of the PIN auxin efflux carriers' family. Here we had used rice, Zea maize and Arabidopsis sequences for the same purpose. One clade PIN5 protein sequences of rice and maize is followed with AtPIN5 sequence; while in the second clade, 
it is divided in to 7 sub-groups PIN9 (OsPIN9 and ZmPIN9).AtPIN6 was observed in a single branch; while PIN2 of all three followed in one sub-clade PIN1 of ZmPIN1 (Fig. 3). OsPIN 1 with their sub types $1 \mathrm{a}, 1 \mathrm{~b}, 1 \mathrm{c}$ and 1d falls in one clade with AtPIN1, AtPIN4, 3 and 7 followed in one sub-clade with $O s P I N 3 a$ and ZmPIN1Oa. In other sub-clade OsPIN3b came with ZmPIN10b PIN8 of rice and maize was observed in one clade with AtPIN8.

The members of auxin efflux carrier proteins associated with auxin transports have been characterised by their presence as integral membrane proteins (Muday and Murphy, 2002). In the present study, all OsPINS proteins were predicted to be membrane localised (Fig. 4) using HMMTOP (Hidden Markov Model for Topology Prediction) method. This was based on the principle that topology of the transmembrane proteins are determined by the maximum divergence of amino acid composition of sequence segments. The long efflux carriers primarily showed polar plasma membrane localisation, provided the directional auxin transport and may play roles in auxin dependent processes in plant development, embryo development, organogenesis and tropism (Blilou et al., 2005). In contrast to long efflux carriers, short efflux carriers have reduced central hydrophilic loops and do not localise to the plasma membrane (Køeèek et al., 2009). Thus, PIN proteins located at rice seed membrane may regulate efflux of the endogenous IAA and PAA from cell to cell.

IAA and PAA play important role in seed cell division and elongation phases, and ultimately the sink size development in rice seeds. Both IAA and PAA docked with auxin receptor and transporter proteins of rice but the efficiency of IAA was more than that of PAA. Auxin efflux PIN proteins of rice showed similarity pattern in phylogenic analysis with maize and Arabidopsis, further supporting the functional implementation of these proteins in the physiology of the rice seeds. Thus, the docking response of auxins with the signaling proteins of rice helps to understand its transport in rice. 


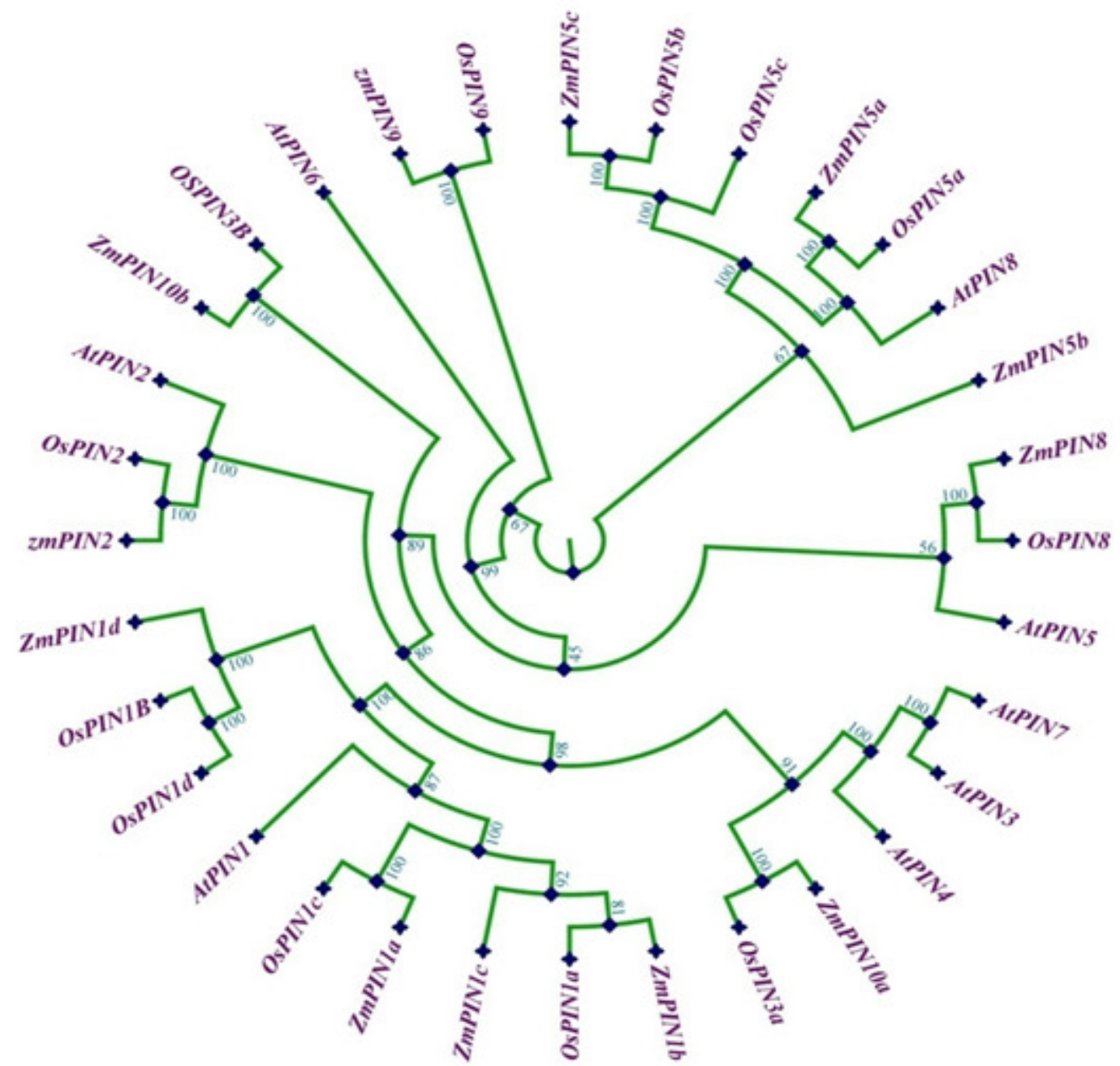

Figure 3. UPGMA Phylogenic trees showing the relationship between Athaliyana(dicot), Maize and rice(monocot) PIN fimily proteins.

TABLE 4. List of the auxin transporters and putative transporters

\begin{tabular}{lll}
\hline Organisms & Name & Uniprot ID \\
\hline Oryza sativa & OsPIN1a & Q0DXM9 \\
& OsPIN1b & P0C0X5 \\
& OsPIN1c & Q0DDD2 \\
& OsPIN1d & D5A7I8 \\
& OsPIN2 & Q0DAE1 \\
& OsPIN3a & D5A7J0 \\
& OsPIN3b & Q6L5F6 \\
& OsPIN5a & Q0JGK0 \\
& OsPIN5b & D5A7J3 \\
& OsPIN5c & Q0J484 \\
& OsPIN8 & Q0JJV0 \\
& OsPIN9 & Q0JIG6 \\
\hline
\end{tabular}


Endogenous IAA, PAA level and its signaling in rice seed

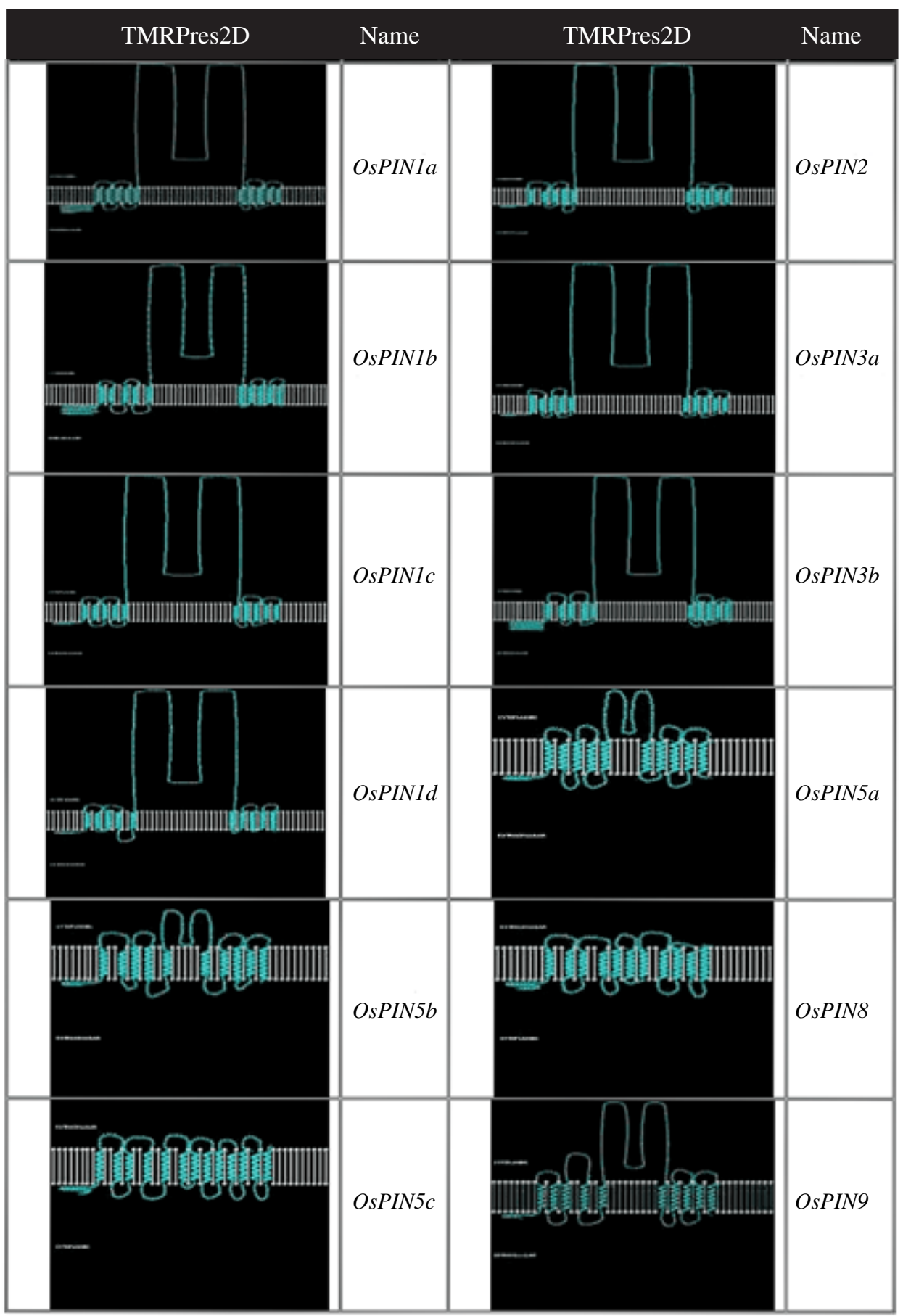

Figure 4. Predicted Membrane-spanning Helices of rice PIN Proteins PIN protein sequences were analysed by HMMTOP (http://wwwenzimhu/hmmtop/) Transmembrane prediction programmes. 


\section{ACKNOWLEDGEMENT}

The authors are thankful to Centre for Advanced Studies in Plant Biotechnology, Genetic Engineering, and State Government for providing laboratory facilities. The authors also thank ASPEE Research Foundation, TANSA Farm, Mumbai, for providing plant materials.

\section{REFERENCES}

Barai, N.J., Gokani, S.J. and Thaker, V.S. 2005. Effect of synthetic and natural auxins on cotton fiber development in vitro. Physiology and Molecular Biology of Plants 11(1):1-4.

Bhatt, K. and Thaker, V. 2008. Effect of 7Li radiation on endogenous hormonal level on developing cotton fiber. Indian Journal of Experimental Biology 46:673-676.

Blilou, I., Xu, J., Wildwater, M., Willemsen, V., Paponov, I., Friml, J., Heidstra, R., Aida, M., Palme, K. andScheres, B. 2005. The PIN auxin efflux facilitator network controls growth and patterning in Arabidopsis roots. Nature 433:39-44.

Chen, J., Lausser, A. and Dresselhaus, T. 2014. Hormonal responses during early embryogenesis in maize. Biochemical Society Transactions 42:325-331.

Chudasama, R. and Thaker, V. 2007. Relationship between gibberellic acid and growth parameters in developing seed and pod of pigeon pea. Brazilian Journal of Plant Physiology 19(1):43-51.

Cristian, F. and Serena, V. 2012. The role of PIN auxin efflux carriers in polar auxin transport and accumulation and their effect on shaping maize. Development Molecular Plant 5(4):787-798.

Dharmasiri, N., Dharmasiri, S. and Estelle, M. 2005a. The F-box protein TIR 1 is an auxin receptor. Nature 435: 441-445.

Dharmasiri, N., Dharmasiri, S., Weijers, D., Lechner, E., Yamada, M. and Hobbie, L. 2005b. Plant development is regulated by a family of auxin receptor $\mathrm{F}$ box proteins. Developmental Cell 9:109-119.

Dubrovsky, J.G. Sauer, M., NapsucialyMendivil, S., Ivanchenko, M.G., Friml, J. and Shishkova, S. 2008. Auxin acts as a local morphogenetic trigger to specify lateral root founder cells. Proceedings of the National Academy of Science 105:8790-8794.

Gokani, S.J. and Thaker, V.S. 2002. Accumulation of abscisic acid in cotton fiber and seed of normal and abnormal bolls. Journal of Agricultural Science 137: 445-451.

Gokani, S.J. and Thaker, V.S. 2002. Physiological and biochemical changes associated with cotton fiber development IX Role of IAA and PAA. Field Crops Research 77:127-136.

Hidehiro, F. and YokoOkushima, M. T. 2007. Auxin-mediated lateral root formation in higher plants. International Review of Cytology 256:111-37.

Jhala, V.M. and Thaker, V.S. 2015. X-ray computed tomography to study rice (Oryza sativa L.) panicle development. Journal of Experimental Botany 66(21):6819-6825. doi:101093/jxb/erv387.

Køeèek, P., Skùpa, P., Libus, J., Naramoto, S., Tejos, R. and Frim, 1.J. 2009. Za•ímalová, E Protein family review the PIN-FORMED (PIN) protein family of auxin transporters. Genome Biology 110:111.

Löbler, M. and Klämbt, D. 1985.Auxin-binding protein from coleoptile membranes of corn (Zea mays L.) I Purification by immunological methods and characterization. Journal of Biological Chemistry 260:9848-9853.

Mockaitis, K. and Estelle, M. 2008. Auxin receptors and plant development: A new signaling paradigm. Annual Review of Cell Developmental Biology 24:55-80.

Muday, G.K. and Murphy, A.S. 2002. An emerging model of auxin transport regulation. Plant Cell 14:293-299. 
Nakum, N., Tank, J.G. and Thaker, V.S. 2013. Influence of phytohormones on growth and development of internodes of $V$ quadrangularis. Plant Archives 13(1): 469-476.

Napier, R.M. andVenis, M.A. 1990. Monoclonal antibodies detect an auxininduced conformational change in the maize auxin-binding protein. Planta 182: 313-318.

Patel, D. and Thaker, V.S. 2007. Estimation of endogenous contents of phytohomones during internode development in Merremia emarginata. Biologia Plantarum 51(1):7579.

Reinecke, D.M. 1999. 4-Chloroindole-3-acetic acid and plant growth. Plant Growth Regulation 27: 3-13.

Reinhardt, D., Therese, M. and Kuhlemeier, C. 2002. Auxin regulates the initiation and radial position of plant lateral organs. The Plant Cell 12(4):507-518.

Sauer, M. and Kleine-Vehn, J. 2011. Auxin binding protein 1: The outsider. Plant Cell 23:2033-2043.

Sibu, S. and Petrá, S. J. 2011. Why plants need more than one type of auxin. Plant Science 180:454-460.

Skoog, F., Miller, C.O. 1957. Chemical regulation of growth and organ formation in plant tissue cultures in vitro. Symposium of Society of Experimental Biology 11:118-131.

Tank, J.G., Pandya, R.V. and Thaker, V.S. 2014. Phytohormones in regulation of the cell division and endoreduplication process in the plant cell cycle. RSC Advances 4:12605-12613.

Thaker, V. 1998. Role of peroxidase and glycosidases in regulation of sink size in developing seeds of Hibiscus esculentum. Acta Physiologia Plantarum 20:179-182.

Thaker, V.S., Saroop, S. and Singh, Y.D. 1986. Physiological and biochemical changes associated with cotton fiber development III Indole-3-acetaldehyde dehydrogenase. Biochemistry Physiologia Pflanzan 181:339-345.

Trevawas, A.J. 1982. Growth substance sensitivity: The liming factor in plant development. Physiologia Plantarum 55:60-72.

Wang, J.R., Hu, H., Wang, G.H., Li, J., Chen, J.Y. and Wu, P. 2009. Expression of PIN genes in rice (Oryza sativa L.): Tissue specificity and regulation by hormones. Molecular Plant 2:823-831.

Weiler, E.W. 1981. Radioimmunoassay for pmol-quantities of indole-3-acetic acid for use with highly stable $\left[{ }^{125} \mathrm{I}\right]-$ and $\left[{ }^{3} \mathrm{H}\right] \mathrm{IAA}$ derivatives as radiotracers. Planta 153:319325.

Wightman, F. and Lighty, D.L. 1982 Identification of phenylacetic acid as a natural auxin in the shoots of higher plants. Physiologia Plantarum 55:17-24.

Xu, T., Dai, N., Chen, J., Nagawa, S. Cao, M. and Li, H. 2014. Cell surface ABP1TMK auxin-sensing complex activates ROP GTPasesignalling. Science 343:1025-1028 